\title{
A csíz (Spinus spinus) előfordulása Délkelet-Magyarországon
}

\author{
BOZÓ LÁSZLó \\ Eötvös Loránd Tudományegyetem, Állatrendszertani és Ökológiai Tanszék, \\ 1117 Budapest, Pázmány Péter sétány 1/C E-mail: bozolaszlo91@gmail.com
}

\begin{abstract}
Összefoglalás. A csíz (Spinus spinus (LinNAEUs, 1758)) az északi félteke tülevelü és lombelegyes erdőkkel borított területein költ. Legtöbb állománya vonuló és tipikus inváziós madárfajnak tekinthető, mivel bizonyos években a szokásosnál jóval nagyobb mennyiségben jelentkezik a telelőterületeken. Magyarországon kis számban fészkel, de az ország nagy részén csak az ösztől tavaszig terjedő időszakban találkozhatunk vele. A hazánkon átvonuló madarak vonulása viszonylag jól ismert, ám ezek a vizsgálatok nagyrészt csak az ország néhány pontján történt gyürüzések eredményeire épülnek, többek között a délkeleti országrészből sem állnak rendelkezésre publikációk. Dolgozatomban egy délkelet-magyarországi terület csízadatait elemeztem, különös tekintettel a faj vonulására, illetve a téli és nyári előfordulásokra. Munkám során elsősorban kézitávcsöves megfigyelésekre támaszkodtam, melynek során 2004 és 2019 között 1811 megfigyelési nap közül 300 napon figyeltem meg csízeket. A madarak tavaszi vonulása március eleje és április vége között zajlott, csúcsa április elején volt, ami az országos átlaghoz képest később van. Az őszi vonulás időzítése (szeptember vége - november vége) hozzávetőleg 10 nappal esik későbbre, mint az országos átlag. Télen meglehetősen ritka, míg nyáron szintén előkerült már a területről. Jellemzően magános madarak vagy kisebb csapatai kerültek szem elé. A vonulás időzítése valószínűleg azért tér el az országos átlagtól, mert ezek a madarak más, vélhetően az Erdélyi-szigethegységből származó populációkból származnak, nem pedig a Kárpát-medencén kívülről.
\end{abstract}

Kulcsszavak: énekesmadár-vonulás, pintyfélék, invázió, Délkelet-Magyarország.

Elfogadva: 2019.11.02.

Elektronikusan megjelent: 2019.12.10.

\section{Bevezetés}

A csíz (Spinus spinus (LiNNAEUS, 1758)) Eurázsia széles körben elterjedt, monotipikus pintyféléje, amelynek két, földrajzilag jól elkülönülő populációja él Európában egészen Oroszország középső részéig, valamint a Távol-Keleten (CLEMENT 2019). Jellemzően síkés hegyvidéki lucfenyvesekben költ (CLEMENT 2019), de esetenként égerlápon is fészkelhet (NAGY 1934). Magyarországon kisszámú fészkelő az Alpokalján, az Örségben, a Bakonyban, a Bükkben és a Zempléni-hegységben (MME NOMENCLATOR BizOTTSÁG 2008). Bár költését már a 20. század első felében is feltételezték a költési időben történő megfigyelések alapján a Soproni-hegységben (GYŐRY 1957), a Kőszegi-hegységben (CHERNEL 1907), a Hanságban (PÁTKAI 1934), a Zempléni-hegységben (SZIJJ 1955) és a Bükkben is (MAUKS 
1924), bizonyítani azonban csak 1959-ben sikerült az utóbbi helyen (SZABÓ \& GYŐRI 1962). Emiatt HARASZTHY (2019) szerint a fajt alkalmi fészkelőnek kell tekinteni Magyarországon, mert az ötvenes évek végén a Bükkben talált két fészkén kívül azóta sem került elö újabb hazánk területén, a június-júliusban megfigyelt fiatalok pedig akár a határ túloldaláról is származhatnak. Évente egyszer, esetleg kétszer költ, első fészekalja márciusban és április elején teljes lehet, míg második költését május végén - július elején kezdi (KÁRPÁTI 1998, HARASZTHY 2019). A fiatalok önállósodását követően kóborlásba kezdenek és már június végén csapatokban mozognak (KÁRPÁTI 1998, HARASZTHY 2019). A költési időszakban esetenként olyan területeken is látták a fajt, ahol egyébként fészkelése nem elképzelhető. MOLNÁR (1995) négy alkalommal is megfigyelte a faj egyedeit a Bakony különböző részein június eleje és július vége között, míg LENNER (1982) a Komárom-Esztergom megyei Sárisáp - Annavölgy térségéből említi július eleji elöfordulását. Nemcsak a hegyés dombvidéken, hanem az Alföldön is felbukkanhatnak átnyaraló egyedek (HARKA 2010).

A költőterület északi részén fészkelő populációk parciális vonulók, míg a déli állományok állandók (HALMOS 2009). Jellemző rá az inváziós hajlam. Azokban az években, amikor a fő tápláléknak számító éger és nyír termése gyengébb a költőterületeken, Európa azon területein is megjelenik, ahol egyébként nem szokott előfordulni (HALMOS 2009). A telelési stratégia nem a populációkra, hanem azok egyedeire jellemzö, hiszen amíg ugyanazon populáció egyes egyedei télen nomád viselkedést mutatnak, másokra erős területhüség jellemző (SENAR et al. 1990, 1992). A nomadizáló madarak még akkor sem feltétlenül maradnak egy adott helyen, ha ott állandó táplálékforrás (pl. madáretető) áll a rendelkezésükre (SENAR et al. 1992). Magyarországon az őszi vonulás szeptember elején kezdődik és egy október közepi-végi csúccsal decemberben ér véget. Tavasszal februárban indul a vonulás, február végén - március elején tetőzik és áprilisra le is cseng (HALMOS 2009), ugyanakkor esetenként még május elején is előfordulhatnak átvonuló egyedek (KÁRPÁTI 1998). A hazánkban átvonuló madarak a gyürüzési adatok alapján elsősorban a Balti-tenger környéki államokból származnak és Olaszországban töltik a telet, de ettől nyugatabbra és keletebbre is elmozdulhatnak (HALMOS \& CSÖRGÖ 1999, HALMOS 2009). Nálunk csak kis számban telel át a faj, föként nyíresekben és égerlápokon (KÁRPÁTI 1998).

Jelen dolgozatomban a csíz délkelet-magyarországi elöfordulását mutatom be, mivel az irodalomban az ország ezen részéről nem találhatunk információt a fajról. Munkám során a faj tavaszi és őszi vonulását írtam le, valamint adatokat közlök nyári és téli előfordulásokról is.

\section{Anyag és módszer}

Az adatok Kevermes és Lökösháza települések mintegy 8000 hektáros kül- és belterületéről származnak, a 2004. október és 2019. június közötti időszakból (1. ábra). A kutatásba bevont terület határának a települések közigazgatási határát tekintettem. A legtöbb megfigyelés a kevermesi sóderbánya környékén található ültetett erdőkből, illetve Kevermes belterületéről származik, de kiemelendő a településtől délre fekvő, szintén ültetett Tábornokerdő is. Az említett erdők domináns fája a nemesnyár, az akác és a nyugati ostorfa, de elegyben szil, kőris, vadkörte, dió és tölgy is elöfordul területükön. A belterületen az átre- 
pülő madarak mellett elsősorban nyírfákon táplálkozó egyedek kerültek szem elé. A különböző években történt megfigyelési napok számát és a pontos megfigyelési időszakokat az 1. táblázat ismerteti.

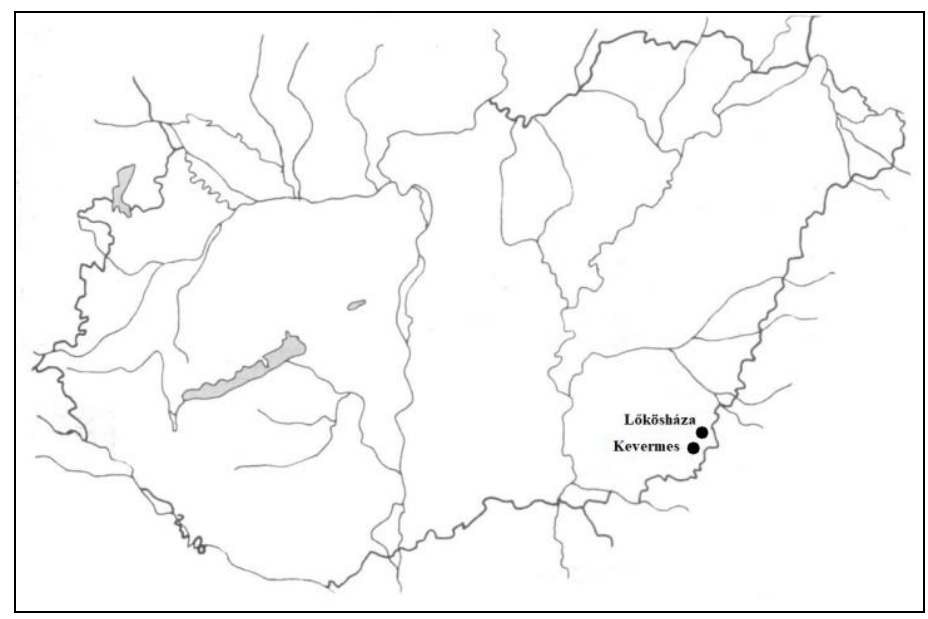

1. ábra. Áttekintő térkép a vizsgálati terület országon belüli elhelyezkedéséről.

Figure 1. The location of the study area within Hungary.

A megfigyeléseket a terület kerékpáros és gyalogos bejárásával, kézitávcső és fényképezőgép használatával végeztem. A madarak határozása általában hang alapján történt, mivel jellemzően átrepülő példányokat figyeltem meg. Adatnak azok a megfigyelési napok számítanak, amelyeken észleltem a fajt. Tavasznak a február 10. és május 10. közti időszakot tekintettem, míg az ősz szeptember 1. és december 10. közé esik.

Az őszi és tavaszi vonulás kezdete átlagának azon napok dátumának átlagait tekintettem, amikor elöször figyelt meg csízt összel, illetve tavasszal. Az öszi és tavaszi vonulási szezonok medián dátumai közti eltérések kimutatásához Kruskal-Wallis tesztet alkalmaztam, míg azt, hogy mely évek vonulása különbözött szignifikánsan egymástól és melyeké nem, Mann-Whitney párosított teszttel vizsgáltam meg.

Mivel a térségben 2010 óta rendszeres madárgyürüzési tevékenységet is folytatok, ezért jelen dolgozatban megemlítem azt a néhány gyürüzési adatot is, ami a fajra vonatkozik. A helyi gyürüzések módszertanáról és eredményeiről korábbi publikációkban már beszámoltam (BOzÓ 2016, 2017, Bozó et al. 2017, BOZÓ \& BOZÓNÉ BORBÁTH 2018), így itt csak annyit tennék hozzá kiegészítésül, hogy egyetlen esetben sem használtam hívóhangot a csízek befogására.

A szövegben található ábrák a Microsoft Excel 2013 program felhasználásával készültek, míg a statisztikai elemzéshez az R 3.2.4 programot használtam (R CORE TEAM 2016). 
1. táblázat. Az évenkénti megfigyelési napok száma és a pontos megfigyelési időszakok.

Table 1. Number of annual observation days and exact observation periods.

\begin{tabular}{ccc}
\hline Év & Megfigyelési napok száma & Időszak \\
\hline 2004 & 25 & október 23. - december 31. \\
2005 & 115 & január 8. - december 31. \\
2006 & 99 & január 1. - december 31. \\
2007 & 97 & január 2. - december 31. \\
2008 & 62 & január 3. - december 25. \\
2009 & 72 & január 12. - december 28. \\
2010 & 22 & január 9. - december 23. \\
2011 & 11 & január 4. - december 22. \\
2012 & 54 & január 18. - december 27. \\
2013 & 204 & január 2. - december 31. \\
2014 & 193 & január 2. - december 31. \\
2015 & 165 & január 1. - december 17. \\
2016 & 161 & január 4. - december 31. \\
2017 & 150 & január 3. - december 31. \\
2018 & 181 & január 1. - december 29. \\
2019 & 106 & január 1. - július 31. \\
\hline
\end{tabular}

\section{Eredmények}

A csíz megfigyelési adatok éven belüli eloszlását a 2. ábra szemlélteti. A legtöbb adat ősszel októberből (115) és novemberből (68), míg tavasszal áprilisból (29) származik. A téli időszakban (december 10. - február 10. között) összesen 28 alkalommal került elő a faj, ám a képet árnyalja a 2015-2016-os inváziója, amikor ebben az időszakban is gyakori volt a területen. Ettől eltekintve, a megfigyelések száma kilencre csökken.

A tavaszi vonulás kilenc év átlaga alapján március 6-án kezdődött $(\mathrm{SD}=20,9)($ legkorábban 2016. február 11-én) és kilenc év átlaga alapján április 25 -án ért véget $(\mathrm{SD}=10,4)$ (legkésőbb 2015. és 2016. május 6-án). A tavaszi vonulás mediánja április 7-én volt (SD = 20,1). A 2013 és 2019 közötti tavaszi vonulási szezonok mediánjai között szignifikáns eltérés mutatkozott (Kruskal-Wallis teszt, $\mathrm{H}=14,83, \mathrm{p}=0,02147$ ). A 2013 és 2015 tavaszi vonulási szezonok mediánértékei szignifikánsan különböztek a többi szezon értékeitől (2. táblázat), ezekben az években ugyanis a vonulás később zajlott.

A nyári időszakban (május 11. - augusztus 31.) összesen négy alkalommal került elő (2013. május 11., Tábornok-erdő, 1 öreg tojó példány; 2014. július 6., Tábornok-erdő, 2 példány; 2015. június 5., belterület, 2 példány; 2016. május 28., sóderbánya, 1 példány). 
A vonulás ősszel 12 év átlaga alapján szeptember 27-én kezdődött $(\mathrm{SD}=9,4)($ legkorábban 2006. szeptember 10-én) és 9 év átlaga alapján november 27-én ért véget $(\mathrm{SD}=6,5)$ (legkésőbb 2015. december 10-én). Az őszi vonulás mediánja október 27-én volt (SD = 18,7). A 2012 és 2018 közötti őszi vonulási szezonok mediánjai között szignifikáns különbség volt (Kruskal-Wallis teszt, $\mathrm{H}=13,02, \mathrm{p}=0,042$ ). A 2015 őszi vonulási szezon mediánértéke szignifikánsan különbözött 2012, 2017 és 2018-as szezonok értékeitől (2. táblázat), 2015-ben ugyanis a vonulás később zajlott.

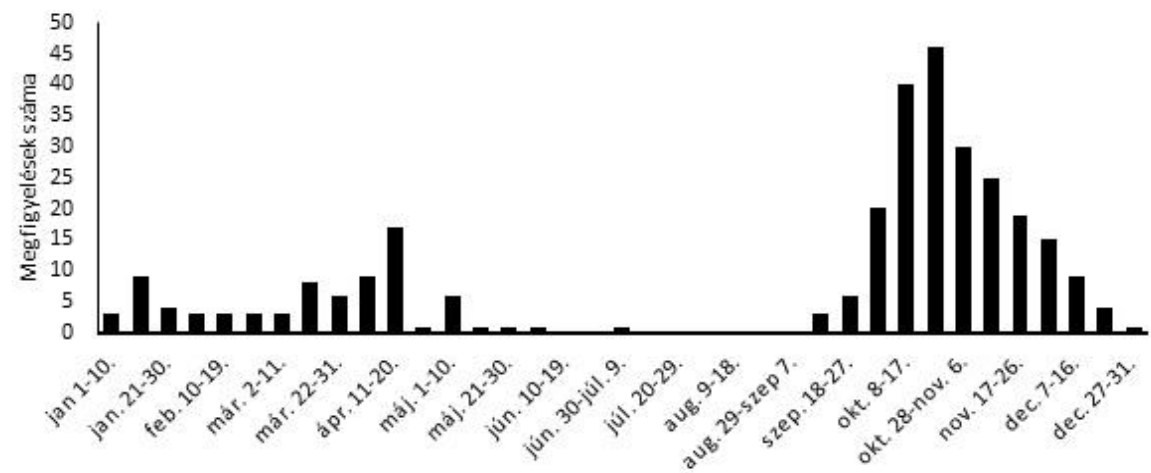

2. ábra. A csíz megfigyelési adatok éven belüli eloszlása.

Figure 2. Distribution of observation data of Eurasian Siskin within year.

A legintenzívebben vizsgált hét telelési szezon (ősztől tavaszig terjedő időszak) során rögzített megfigyelések számát a 3. ábrán mutatom be. Ebböl jól látszik, hogy a 2012 őszétől 2019 tavaszáig terjedő időszakban a legtöbb megfigyelés a 2015-2016-os szezonban volt (66), egyébként 21 és 37 között mozgott a szezononkénti megfigyelések száma.

A csízek csapatainak létszáma átlagosan 3,4 példány volt $(\mathrm{SD}=3,8)$. A legtöbb esetben (41 adat, 37,3\%) magános madarak kerültek szem elé, a 2-5 madárból álló csapatok aránya összesen 48,2\% volt, míg 6 vagy annál több példányos csapatokat csak az esetek 14,6\%ában figyeltem meg. Legnagyobb csapata 20 példányos volt (2005. november 9.).

A 2015/16-os inváziója során október 26. és december 16. között nyolc példányt gyürüztem meg a sóderbánya területén (ebből hét fiatal és egy öreg korú, ill. hat hím és két tojó ivarú volt). Ezen kívül a fácántelepnél lévő belvízelvezető csatornában is fogtam egy fiatal hímet 2018. október 15-én. 
2. táblázat. A különböző tavaszi és őszi vonulási szezonok közti különbségek (Mann-Whitney párosított teszt p értékei).

Table 2. Differences between the different migration seasons in spring and autumn ( $\mathrm{p}$ values of Mann-Whitney pairwise test).

\begin{tabular}{cccccccc}
\hline Tavasz & 2013 & 2014 & 2015 & 2016 & 2017 & 2018 & 2019 \\
\hline 2013 & - & 0,1408 & 0,2339 & 0,5103 & $\mathbf{0 , 0 2 7 5}$ & $\mathbf{0 , 0 0 9 7}$ & $\mathbf{0 , 0 0 1 1}$ \\
2014 & 0,1408 & - & 0,1939 & 0,9146 & 0,5892 & 0,6689 & 0,6430 \\
2015 & 0,2339 & 0,1939 & - & 0,3923 & 0,0538 & $\mathbf{0 , 0 2 5 2}$ & $\mathbf{0 , 0 1 0 9}$ \\
2016 & 0,5103 & 0,9146 & 0,3923 & - & 0,8597 & 0,9362 & 0,9530 \\
2017 & $\mathbf{0 , 0 2 7 5}$ & 0,5892 & 0,0538 & 0,8597 & - & 0,8594 & 0,5365 \\
2018 & $\mathbf{0 , 0 0 9 7}$ & 0,6689 & $\mathbf{0 , 0 2 5 2}$ & 0,9362 & 0,8594 & - & 0,7679 \\
2019 & $\mathbf{0 , 0 0 1 1}$ & 0,6430 & $\mathbf{0 , 0 1 0 9}$ & 0,9530 & 0,5365 & 0,7679 & - \\
\hline Ösz & 2012 & 2013 & 2014 & 2015 & 2016 & 2017 & 2018 \\
\hline 2012 & - & 0,1663 & 0,1232 & $\mathbf{0 , 0 0 5 9}$ & 0,2706 & 0,8466 & 0,4040 \\
2013 & 0,1663 & - & 0,8716 & 0,0722 & 0,9834 & 0,1793 & 0,5333 \\
2014 & 0,1232 & 0,8716 & - & 0,1488 & 0,8755 & 0,1455 & 0,4039 \\
2015 & $\mathbf{0 , 0 5 9 0}$ & 0.0722 & 0,1488 & - & 0,1532 & $\mathbf{0 , 0 1 0 8}$ & $\mathbf{0 , 0 1 9 7}$ \\
2016 & 0,2706 & 0,9834 & 0,8755 & 0,1532 & - & 0,2654 & 0,6059 \\
2017 & 0,8466 & 0,1793 & 0,1455 & $\mathbf{0 , 0 1 0 8}$ & 0,2654 & - & 0,4758 \\
2018 & 0,4040 & 0,5333 & 0,4039 & $\mathbf{0 , 0 1 9 7}$ & 0,6059 & 0,4758 & - \\
\hline
\end{tabular}

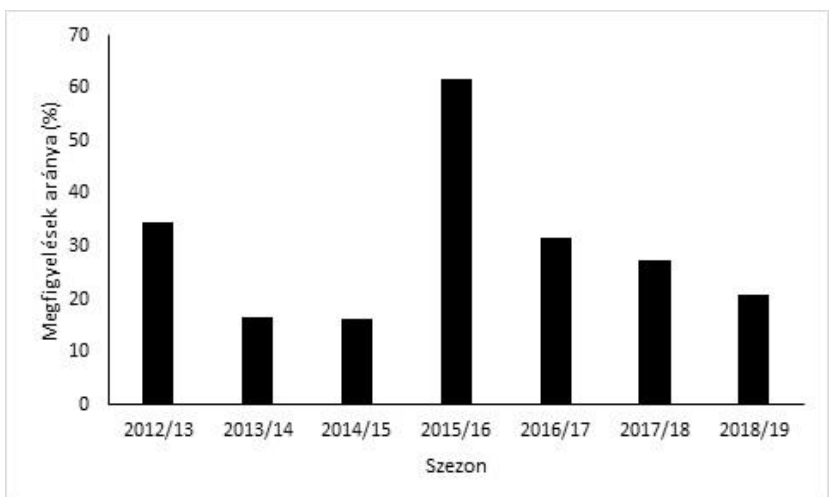

3. ábra. A legintenzívebben vizsgált hét telelési szezon (2012 őszétől 2019 tavaszáig) során rögzített megfigyelések. Az ábrán közölt százalékos adatok azt jelzik, hogy a terepen töltött napok hány százalékában észleltem a fajt.

Figure 3. The number of observations recorded during the seven most intensively studied wintering seasons (autumn 2012 to spring 2019). The values shown in the figure indicate the ratio between the days when I did field observations and when I observed the species. 


\section{Értékelés}

Eredményeim szerint a csíz rendszeres tavaszi és őszi átvonuló, ill. kisszámú téli vendég és ritka nyári kóborló Békés megye délkeleti részén. Tavaszi vonulásuk jellemzően március elején kezdődik el és átlagosan április végén ér véget egy április eleji csúccsal. Ez a mintázat eltér a hazai gyürüzési eredmények alapján megállapított dinamikától, miszerint a faj vonulása február végén - március elején tetőzik és áprilisra lecseng (HALMOS 2009). Az eltérés oka minden bizonnyal az lehet, hogy ezen a területen más populációk egyedei vonulnak át, mint amiket nagy számban gyürüztek az ország különböző, elsősorban középső részein. Ezt támasztja alá az a tény, hogy a faj Magyarországon gyürüzött külföldi vonatkozású, valamint a külföldön gyürüzött és hazánkban visszafogott madarak adatai Európa minden területéröl származnak, nincs határozott vonulási irány, így azok szinte bármelyik fészkelö populáció tagjai lehetnek (HALMOS \& CsÖRGŐ 1999, HALMOS 2009). A csíz hozzánk legközelebb az Erdélyi-szigethegységben költ (BIRDLIFE INTERNATIONAL 2019), ám ezen a területen nincs rendszeres madárgyürüzés, így a helyi állomány vonulási irányáról sincs információ. A tavaszi vonulás eltérő időzítése tehát valószínűleg azért van, mert a madarak nem a Kárpát-medencén túlról, hanem annak területéről származhatnak. Az Erdélyi-szigethegységgel való kapcsolatot feltételezik a faj május eleji adatai is, hiszen a hó elején több esetben is szem elé kerültek egyedei. KÁRPÁTI (1998) említést tesz alkalmi május eleji vonulásról is, ám HALMOS (2009) a teljes hazai gyürüző adatbázist figyelembe véve erről nem ír. Feltételezhetnénk akár kapcsolatot is az inváziós évek és ezen késői adatok között, méghozzá úgy, hogy inváziós években elhúzódik a madarak vonulása, ám az adataink ezt egyáltalán nem támasztják alá. Ennek nyomán pedig még inkább helytálló az a korábbiakban felvázolt elképzelés, miszerint a nálunk átvonuló, valószínüleg az Erdélyiszigethegységben fészkelő populáció vonulása eltér az országos átlagtól és rendszeresen elhúzódhat május első harmadáig.

A nyári adatok május közepe és július eleje között szórnak, hasonlóan az irodalomban fellelhető, az ország különböző pontjairól származó, nem helyben fészkelő madarak adataihoz (LENNER 1982, FENYÖSI 1994, MOLNÁR 1995, HARKA 2010). Az időszak első felében megfigyelt egyedek valószínűleg költésből kimaradt példányok, míg a június-júliusi madarak akár már azévi fiatalok is lehetnek, amelyek költés utáni diszperziós mozgásuk révén juthattak el hozzánk.

Az őszi vonulás szeptember vége és november vége között zajlott október végi csúccsal, ami nagyjából egybeesik az országban általánosan jellemző vonulási időszakkal (HALMOS 2009). Annyi különbség azonban mégis mutatkozik, hogy a kutatási területemen egy dekáddal későbbre tolódik a vonulási hullám. Ennek hátterében egyaránt állhatnak a fentiekben részletezett populációs különbségek, kiegészítve annyival, hogy a későbbi tavaszi vonulás miatt valószínüleg a madarak költése is eltolódik, ami miatt később kezdik el az őszi vonulásukat. Másik lehetséges magyarázat lehet az is, hogy a fajt jelentős részben tőlünk északabbra fekvő gyürüzőállomásokon jelölték, így több idő kell nekik, amíg eljutnak a délebben fekvő földrajzi szélességekre. Egy korábbi tanulmányban hasonló mintázatot találtunk a sisegö füzike (Phylloscopus sibilatrix) és csilpcsalpfüzike (Ph. collybita) esetén is (BOZÓ \& BOZÓNÉ BORBÁTH 2018).

Télen csak kis számban lehet csízekkel találkozni a térségben, aminek legvalószínübb magyarázata az, hogy nincsenek olyan táplálkozóhelyek (nyír- és égerfák), amelyek alkal- 
masak lennének a faj számára huzamosabb ideig történő helyben tartózkodásra. Másrészt pedig egyáltalán nem jellemző a fajra a szezonon belüli telelőterület-hüség, még olyan helyeken sem, ahol egyébként nagy mennyiségü és állandó táplálékforrás áll a rendelkezésükre (SENAR et al. 1992), így nem is lehet elvárni, hogy rendszeresen feltünjenek a területen.

Ahogy korábban említettem, jellemző rá az inváziós hajlam, jelentősebb invázióit azonban csak ritkán jegyezhetjük fel. HALMOS (2009) a gyürüzési adatok alapján 2006-ig csupán három olyan évet $(1975,1985,2000)$ emel ki, amikor a hazánkban gyürüzött csízek száma meghaladta az 5000 példányt, míg a 2006 és 2018 közötti időszakban egyetlen ilyen év sem volt Magyarországon (MAGYAR MADÁRTANI ÉS TERMÉSZETVÉDELMI EGYESÜLET 2019). Ennek ellenére a kutatási területemen a 2015/16-os szezon során jelentősebb invázióját tapasztaltam. Ebben a szezonban hozzávetőleg kétszer annyi adata volt a fajnak a területről, mint a többi szezonban és voltak áttelelő példányok is. Ennek a helyi inváziónak a hátterében a nálunk átvonuló populációknál bekövetkezett kimagasló költési siker, illetve ezzel összefüggésben a fészkelöterületeken fellépö táplálékhiány állhat.

Nincsen elegendő mennyiségű adatunk az átvonuló madarak ivararányára vonatkozóan, ugyanakkor az eddig gyürüzött kilenc madárból hét hím volt. Ez párhuzamba állítható PAYEVSKY (1994, 2012) eredményeivel a Balti-tenger keleti részén, miszerint a hímek mind a tavaszi, mind az őszi vonulás során nagyobb arányban vannak jelen a csapatokban, mint a tojók. Ez a megállapítás a legtöbb telelöterületre igaz (HALMOS 2009), de természetesen az alacsony mintaelemszám miatt helyi szinten nem lehet határozott kijelentést tenni.

A csapatok átlagos példányszáma $(3,4)$ jóval alacsonyabb, mint amit KÁRPÁTI (1998) leírt. Szerinte a csapatok átlagos példányszáma csak ritkán kevesebb 10-20-nál, néha pedig akár százas nagyságrendủek is lehetnek azok. Még a 2015/16-os inváziója során sem voltak nagy példányszámú csapatok, téli és nyári előfordulásai során pedig egy-két példánynál több nem szokott szem elé kerülni. KÁRPÁTI (1998) megfigyelései minden bizonnyal a hegyvidéki, illetve az ország középső részein található, a csízek számára megfelelő táplálékforrással rendelkező területein történtek. Az ország délkeleti csücskében, ahol a szántóföldek aránya 90\% feletti, nincsenek megfelelö táplálkozóhelyek, így minden bizonnyal ezért nincsenek nagy egyedszámú csapatok. A másik magyarázat pedig az lehet, hogy jóval kisebb földrajzi területről érkeznek ide a madarak, például az Erdélyi-szigethegységből és ezért nincsenek több százas csapatok.

A jelenlegi eredmények terepi megfigyeléseken alapszanak, míg az országos adatok elsősorban gyürüzéseken. Éppen ezért célszerü lenne a jövőben intenzívebben jelölni helyi szinten is a fajt, ám ezt valószínúleg csak hívóhang használatával lehetne kivitelezni, ami pedig befolyásolná az eddigi standard mintavételezést. A terepi adatgyüjtés mindazonáltal a továbbiakban is folytatódni fog és a jövőben talán sikerülhet további bizonyítékokat találni a Délkelet-Magyarország és az Erdélyi-szigethegység közötti kapcsolatra, amit például az uráli bagoly (Strix uralensis) (Bozó subm.) és a hegyi fakusz (Certhia familiaris) (Bozó 2017) esetében is feltételezek. 


\section{Irodalomjegyzék}

BirdLife InTERNATIONAL (2019): Species factsheet: Spinus spinus. http://www.birdlife.org (megtekintés 2019.04.24.)

Bozó, L. (2016): A madárgyürüzés eredményei a kevermesi sóderbánya területén 2012-2016 között. A Száraz-ér társaság kutatásai 2011-2015 között, pp. 35-38.

Bozó, L. (2017): Kevermes madárvilága. Dél-békési Természetvédelmi és Madártani Egyesület, Kevermes, $121 \mathrm{p}$.

Bozó, L., BozÓNÉ BORBÁTH, E. \& TAR, L. (2017): Énekesmadarak őszi vonulása csatornaparti fasoron. Természetvédelmi Közlemények 23: 1-13.

Bozó, L. \& BozÓNÉ Borbáth, E. (2018): A csilpcsalpfüzike (Phylloscopus collybita), a fitiszfüzike (Ph. trochilus) és a sisegö füzike (Ph. sibilatrix) vonulása a Dél-Tiszántúlon. Állattani Közlemények 103(1-2): 47-72. https://doi.org/10.20331/AllKoz.2018.103.1-2.47

Chernel, I. (1907): Adatok Magyarország madárfaunájához. Aquila 4(1-4): 179-187.

Clement, P. (2019): Eurasian Siskin (Spinus spinus). In: DEl Hoyo, J., Elliott, A., SARgatal, J., Christie, D. A. \& DE JuAna, E. (eds.): Handbook of the Birds of the World Alive. Lynx Edicions, Barcelona. https://www.hbw.com/node/61340 (megtekintés 2019.03.31.)

FENYŐsI, L. (1994): Adatok a csíz (Carduelis spinus) nyári előfordulásaihoz. Madártani Tájékoztató 18(2): 24.

GYŐRY, J. (1957): Süvöltők és csízek tavaszi előfordulása. Aquila 63-64: 310.

HALmos, G. \& CSÖRGÖ, T. (1999): Migration and wintering of Finches (Fringillidae) in the Charpathian Basin based on ringing recoveries. Ornis Hungarica 8(9): 1-12.

Halmos, G. (2009): Csíz. In: CsÖrgö, T., Karcza, Zs., Halmos, G., MAGYar, G., Gyurácz, J., SzÉP, T., BAnkovics, A., SChMidT, A. \& SChMidT, E. (eds): Magyar madárvonulási atlasz. Kossuth Kiadó, Budapest, pp. 612-615.

HARASZTHY, L. (2019): Magyarország fészkelö madarainak költésbiológiája. 2. kötet Sárgarigóféléktöl a sármányfélékig. Pro Vértes Nonprofit Kft., Csákvár, pp. 703-705.

HARKA, Á. (2010): Átnyaraló csíz (Carduelis spinus) az Alföld közepén. Calandrella 13: 223.

KÁRPÁTI, L. (1998): Csíz. In: HARASzThy, L. (ed.): Magyarország madarai. Mezőgazda Kiadó, Budapest, p. 369.

LENNER, J. (1982): Csíz (Carduelis spinus) adatok Sárisáp-Annavölgy környékéről. Madártani Tájékoztató 6(1): 34.

Magyar MadÁRTAni És Természetvédelmi Egyesület (2019): Magyarország madarai: Csíz. http://www.mme.hu/magyarorszagmadarai/madaradatbazis-carspi (megtekintés 2019.04.24.)

MAUKs, K. (1924): A Bükk-fennsíkon 1923. aug. 8-18 között megfigyelt madárfajok. Aquila 30-31: 298.

MME Nomenclator BizotTSÁg (2008): Magyarország madarainak névjegyzéke. Nomenclator avium Hungariae. Magyar Madártani és Természetvédelmi Egyesület, Budapest, 278 p.

MolnÁR, I. (1995): Csíz (Carduelis spinus) előfordulási adatok költési időből. Madártani Tájékoztató 19(2): 32-33.

NAGY, J. (1934): Az első csíz fészekalj Magyarországról. Aquila 38-41: 348-349. 
PAYeVsKy, V. A. (1994): Age and sex structure, mortality and spatial winter distribution of Siskins (Carduelis spinus) migrating through eastern Baltic area. Vogelwarte 37: 190-198.

PAyevsky, V. A. (2012): Speed of autumn migration of the Siskin Carduelis spinus moving across Europe as shown by ringing results in Eastern Baltic. Avian Ecolology and. Behaviour 21: 13-25.

PÁtKai, I. (1934): Csízek a Hanyságban. Aquila 38-41: 350.

R Development Core Team (2016): R: A language and environment for statistical computing. R Foundation for Statistical Computing, Vienna, Austria.

Senar, J. C., Lleonart, J. \& MetCalfe, N. B. (1990): Dominance relationships between resident and transient wintering Siskin. Ornis Scandinavica 21: 129-132. https://doi.org/10.2307/3676808

Senar, J. C., Burton, P. J. K. \& Metcalfe, N. B. (1992). Variation in the nomadic tendency of a wintering finch Carduelis spinus and its relationship with body condition. Ornis Scandinavica 23(1): 63-72. https://doi.org/10.2307/3676428

SzABÓ, L. V. \& GYöRY, J. (1962): Csíz fészkelése a Bükkhegységben. Aquila 67-68: 141-149. https://doi.org/10.1001/archopht.1962.00960030153028

SzIJJ, L. (1955): Adatok a Sátorhegység madárvilágához. Aquila 59-62: 417-418. 


\title{
The occurrence of Eurasian Siskin (Spinus spinus) in Southeast Hungary
}

\author{
LÁSZLó BOZÓ \\ Department of Systematic Zoology and Ecology, Eötvös Loránd University, Pázmány Péter sétány 1/C, \\ H-1117 Budapest, Hungary E-mail: bozolaszlo91@gmail.com
}

\begin{abstract}
ÁLLATTANI KÖZLEMÉNYEK (2020) 105(1-2): 59-69.
\end{abstract}

\begin{abstract}
The Eurasian Siskin (Spinus spinus (LinNaEus, 1758)) breeds in coniferous and mixed forests of the Northern Hemisphere. Most of its populations can be considered migratory and it is a typical invasive bird species. It breeds in small number in Hungary, but in most parts of the country can only be found from autumn to spring. The migration of birds passing through Hungary is relatively well known, but these studies are based mainly on the results of ringing activities in the middle of the country. In this study I analyzed the data of Eurasian Siskin in Southeast Hungary, with special regard to their migration, winter and summer occurrences. During my work I mainly used field observation data, during which I observed Siskins on 300 different days out of the 1811 days spent in the area between 2004 and 2019. The spring migration of birds occurred between early March and the end of April, with a peak in early April, which is later than the average migration timing of birds migrating in other parts of Hungary. The timing of the fall migration (end of September - end of November) is about 10 days later than the national average. It is quite rare in winter, while it has also been found in summer. Based on the results these birds are most likely originated from the Apuseni Mountains and not from outside the Carpathian Basin.
\end{abstract}

Key words: passerine migration, Finches, invasion, Southeast Hungary.

Accepted: 02.11.2019

Published online: 10.12.2019 